\title{
Tall herb dark coniferous forests as modern refugia of biological diversity of Northern Eurasia (on example of Pechora-llych Nature Reserve)
}

\author{
Olga V. Smirnova ${ }^{1 *}$, Anna P. Geraskina ${ }^{1}$, and Vladimir N. Korotkov ${ }^{2}$ \\ ${ }^{1}$ Center for Forest Ecology and Productivity RAS, Profsoyuznaya st. 84/32, Moscow, 117997, Russia \\ ${ }^{2}$ Yu.A. Izrael Institute of global climate and ecology, Glebovskaya st., 20B, Moscow, 107258, Russia
}

\begin{abstract}
Reconstruction of prehistoric forests can be based on restoring the areas of key species of plants and animals in those still preserved in refugiua which include tall herb forests. The main characteristic of unique boreal tall herb spruce-fir forests (association of Aconito septentrionalisPiceetum obovatae) is presented in comparison with green moss spruce-fir forests (Eu-Piceetum abietis) that dominate in the taiga zone. Using the example of tall herb forests in the Pechora-Ilych Nature Reserve, we identified the following signs of intact forests of the Northern Eurasia: high diversity of vascular plant and moss species; full set of microsites connected with a tree-falls, well-defined gap-mosaic; diversity of ecological-coenotic groups; uneven-aged structure of tree species populations; fertile soil and rich soil biota; presence of broad-leaved forest markers such as ephemeroids (Corydalis solida, Anemone spp., Gagea $s p p$., etc.); presence of broad-leaved tree species in paleo-spectra. The northern dark coniferous forests may also be regarded as historic refugiua because they were less disturbed by humans and probably less exposed to fire. Such model reconstructions will form the basis for developing methods for restoring the pre-anthropogenic dark coniferous (taiga) forests of Northern Eurasia.
\end{abstract}

\section{Introduction}

At present, we have available a large array of paleodata and a detailed history of nature management for analysis the current state of living cover. Reconstruction of prehistoric forests can be based on restoring the areas of key species of plants and animals in those still preserved in refugia, which include tall herb forests with rich flora [1-3], fertile soils [4] and rich soil biota [5,6]. Such model reconstructions will form the basis for developing methods for restoring the pre-anthropogenic dark coniferous (taiga) forests of Northern Eurasia.

In-depth studies conducted in Russian natural reserves revealed tall herb taiga forests that have not previously been explored, i.e., association of Aconito septentrionalis-

* Corresponding author: ovsinfo@gmail.com 
Piceetum obovatae Zaugolnova et Morozova 2009 [7]. Parts of those forests are found in Northern Eurasia within $30-90^{\circ}$ east longitude and $50-70^{\circ}$ north latitude. To assess the importance of tall herb forests in maintaining the species and structural diversity of the taiga belt, we aimed to compare the main characteristics of tall herb forests and green moss forests (association of Eu-Piceetum abietis (Caj. 1921) K.-Lund 1962) that dominate most of the taiga belt.

The purpose of this work: assessing the state and identifying conservation criteria for tall herb dark coniferous forests of the Northern Urals.

\section{Materials and methods}

The material was collected in the upper reaches of the Pechora River in the foothills of the Pechora-Ilych State Nature Reserve (within $62-63^{\circ} \mathrm{N}$ and $58-59^{\circ} \mathrm{E}, 250-400 \mathrm{~m}$ above sea level). The Pechora-Ilych Reserve is a long-established protected area of the Northern Urals (1930 year), which in turn determined the conservation of the natural properties of forests growing there. The research area has a continental climate with average annual air temperatures below zero $\left(-0.8\right.$ to $\left.-2.5^{\circ} \mathrm{C}\right)$. The average duration of the frost-free period is $80-83$ days. The vegetation cover of the foothill part of the reserve is represented by dark coniferous forests. The dominant tree species are Picea obovata Ledeb., Abies sibirica Ledeb. and Pinus sibirica Du Tour. According to radio-carbon dating, this area has been poorly developed for the last 500 years. In Upper Pechora, which is difficult to access for anthropogenic transformation, there were no clear cuts and large fires $[8,9]$.

Studies were performed in 2007-2018 in two types of taiga forests: boreal tall herb spruce-fir forests (association of Aconito septentrionalis-Piceetum obovatae), a unique type found solely in this area (Fig. 1A); green moss spruce-fir forests (Eu-Piceetum abietis) that dominate in the taiga zone (Fig. 1B).

To describe the communities of both associations, 0.25-ha sample plots (SP) were established. Descriptions were made for each SP phytosociological parameter and soil profile. It was completed 32 geobotanical descriptions in boreal tall herb spruce-fir forests and 16 - in green moss spruce-fir forests and areas of microsites were registered. To assess the above-ground and belowground phytomass of vascular plants in 6 types of microsites of boreal tall herb spruce-fir forests and in 3 types microsites of green moss spruce-fir forests, monoliths $0.5 \times 0.5 \mathrm{~m}$ in size were taken in three replications (the depth of a monolith depended on the depth of the root layer). The resulting material was cleaned, sorted out by species and weighed in a completely dry state.
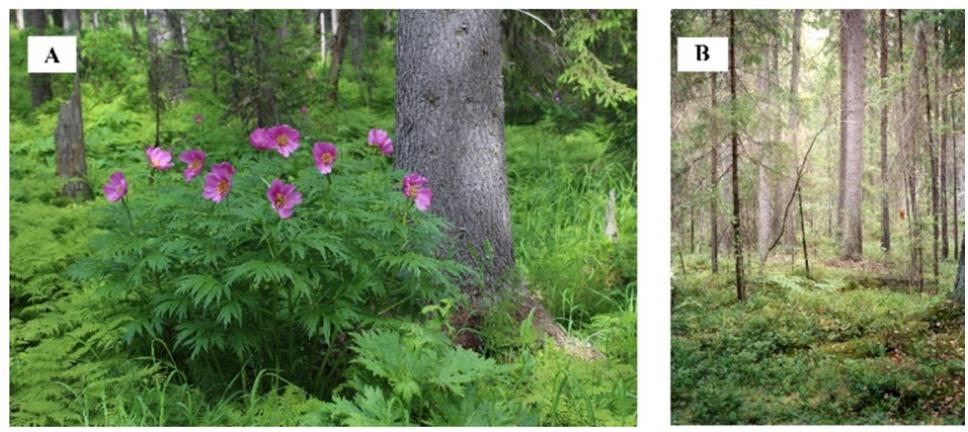

Fig. 1. Forests in Pechora-Ilych State Nature Reserve: A - boreal tall herb spruce-fir forests, B - green moss spruce-fir forests (photo by A.A. Aleinikov).

Based on ecological-coenotic classification, the combined groups of vascular plants are identified: tall herbs $-\mathrm{Hh}$, nitrophilic herbs $-\mathrm{nt}$, nemoral medium herbs- Nm, nemoral 
small herbs- nm, boreal herbs - br-h, boreal ferns - br-fern, boreal dwarf shrubs - br-dw, meadow herbs - md, oligotrophic herbs - olg [1].

\section{Result and discussion}

Tall herb forests showed significant species diversity (Fig 2.) and diversity of ecologicalcoenotic groups of vascular plants. They were dominated by species of the tall herb group of vascular plants (Aconitum septentrionale Koelle, Cacalia hastata L., Crepis sibirica L., Delphinium elatum L., Paeonia anomala L., Pleurospermum uralense Hoffm., Thalictrum minus L., etc.) that contribute most to the biomass of the ground cover $\left(2516.4 \mathrm{~g} \cdot \mathrm{m}^{-2}\right)$, whereas the proportion of green mosses in the total phytomass was rather small $\left(456.8 \mathrm{~g} \cdot \mathrm{m}^{-2}\right)$. The total phytomass of vascular plants in the tall herb forest $\left(3038.0 \mathrm{~g} \cdot \mathrm{m}^{-2}\right)$ was 5.7 times higher than that of the green moss forest $\left(535.6 \mathrm{~g} \cdot \mathrm{m}^{-2}\right)$.

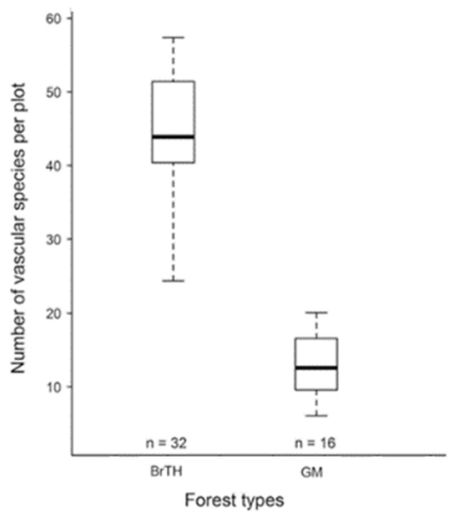

Fig. 2. Boxplots of the numbers of vascular species per plot for tall herb forest $(\mathrm{BrTH})$ and green moss forest (GM).

Tall herb and green moss spruce-fir forests show marked differences in types of their microsites. Six types of microsites have been identified in tall herb forests: 1) under-crown areas within the projection of the tree crown; 2) inter-crown areas between mature trees covered by herbs and dwarf shrubs; 3 ) near-trunk swellings at the base of a mature tree with rotting litter; 4) tree-fall mounds; 5) tree-fall pits; 6) fallen logs - elements of the tree-fall mosaic that are formed after large trees with good vitality and fully developed root system die of old age. Tree-fall mounds in tall herb forests can be $1 \mathrm{~m}$ high or more, and the depth of the pit is approximately the same.

In a green moss forest, three types of microsites have been identified: under-crown areas, inter-crown areas, and fallen logs. In this forest type, there are neither tree-fall mounds nor pits. This phenomenon is due to low vitality of trees and poorly developed root system, so tree death does not result in the formation of mounds and pits; the trunk breaks off at the bottom of the tree and there are fallen tree trunks on the surface.

Green moss forests were characterized by low species diversity (Fig. 3), and a significant proportion of green mosses $\left(2166.4 \mathrm{~g} \cdot \mathrm{m}^{-2}\right)$ in the total phytomass of the ground cover $\left(2582.0 \mathrm{~g} \cdot \mathrm{m}^{-2}\right)$. Among ecological-coenotic groups are predominate boreal groups, nemoral herbs are very rare, meadow herbs and nitrophilic herbs are absent.

In tall herb forests, there were only microsites dominated by mosses - the fallen trunks, which is a much poorer substrate than the soils (brown soils) under tall herbs. The dominance of green moss cover in green moss forests means that the soils of these forests cannot meet the needs of tall herbs in terms of mineral elements. Research into the history 
of taiga forests indicates that the "poverty" of green moss forests is mainly caused by multiple anthropogenic fires that occurred during the development of this territory [8].

The floristic composition in the unique tall herb spruce-fir forests includes all ecological-coenotic groups of vascular plants that were identified in Pechora-Ilych Nature Reserve: tall herbs, nitrophilic herbs, nemoral medium herbs, nemoral small herbs, boreal herbs, boreal ferns, boreal dwarf shrubs, meadow herbs and oligotrophic herbs. The maximum contribution to the total biomass of the ground cover is made by the group of tall herb species ( $90 \%$ of the biomass).

The unique tall herb spruce-fir forests shelter a significant part of the general vascular plant flora of the Northern Eurasia forest belt. These plants include species that are markers for all major types of forests, from dark coniferous to broad-leaved ones, whereas typical spruce-fir forests are dominated only by boreal species. An additional sign of the tall herb spruce-fir forests is presence of broad-leaved forest markers such as early spring plants (ephemeroids): Corydalis solida (L.) Clairv., Anemone altaica Fisch. ex C.A.Mey., Gagea lutea (L.) Ker Gawl., etc. To date, 50 species from the tall herb group have been found in the tall herb forests of the northern Urals [10].

Tall herb forests are dominated by coarse humus brown soils. They have the following diagnostic properties: well-structured humus horizon, visible profile colouring with organic matter, weak profile differentiation by granulometric composition, relatively high organic matter content (3.5-5.5\%), slightly acidic water $\mathrm{pH}$ (5.0 to 6.2$)$ and relatively good content of calcium, potassium and phosphorus compared to soils of other forest types. As far back as the 18th century, soil scientists called such soils "Northern Chernozem". Brown soils create the most favourable environment for the development of communities that contain deciduous trees and herbs, which need a period of intensive spring absorption of biophile elements.

The soil cover of green moss forests is dominated by iron-metamorphic soils, or rusty soils. They can be regarded as a transitional taxon from gleyey podzolic soils to gleysols. The profile colour is uneven and marbled, features that reflect the local areas of redistribution of reduced and oxidised forms of iron. The humus horizon is poorly expressed. In terms of textural classification, rusty soils are mainly medium- and heavyloamy; water $\mathrm{pH}$ of the litter is 3.8-4.6. [4].

The soil macrofauna of the two types of forest was found to include 67 species of invertebrates that belong to 41 families of four classes (Insecta, Arachnida, Chilopoda and Clitellata). Furthermore, these species represent five trophic groups (predators and myxophagous, polyphagous, phytophagous and saprophagous individuals). There is a higher proportion of predators in the green moss forests, whereas the tall herb forests have more saprophages [5]. The saprophages that enable the initial stages of plant residue mineralisation are dominated by earthworms in terms of biomass [5,6]. Five species of earthworms live in the tall herb forest; their number and biomass are 25 ind. $\cdot \mathrm{m}^{-2}$ and 17 $\mathrm{g} \cdot \mathrm{m}^{-2}$, respectively. Earthworms inhabit the soil, litter and fallen logs at different stages of decomposition. Two earthworm species live in the green moss forest; their number and biomass are 5 ind. $\cdot \mathrm{m}^{-2}$ and $1.1 \mathrm{~g} \cdot \mathrm{m}^{-2}$, respectively. In some years, earthworms were only reported to be found in the fallen logs at late stages of decomposition [6].

An analysis of historical archival and radiocarbon data of this territory shows that in the inaccessible areas of the upper Pechora River, where refugia of high-tinned forests have been preserved, there have been no anthropogenic transformations for at least 500 years. The age of the stand of bilberry-green-moss forests is about 150 years and, probably, these communities underwent different anthropogenic transformation $[8,9]$.

Analysis of paleontological data on bone remains of key species of large mammals to date, shows that animal bones dated back to the end of the Pleistocene till the Mesoholocene have been found in the Northern Urals in the upper reaches of the Pechora 
River. Those are the bones of the cave lion, bison, horse, beaver, red deer, saiga, musk ox and woolly rhinoceros, porcupine, and others [11]. A large number of various herbivores were caused by the predominance of forest-meadow landscapes in the territory of modern dark coniferous forests (taiga), where herbs dominated the vegetation. These ideas are confirmed in the experiments of S.A. Zimov on reintroduction of large herbivores in the northeastern Yakutia and in numerous experiments in natural and artificial pasture ecosystems [12].

\section{Conclusions}

The unique tall herb dark coniferous forests of the Northern Urals maintain signs of preanthropogenic forests, specifically in the composition of the spring (ephemeroids) and summer flora. Using the example of tall herb forests, we identified the following signs of preservation of pre-anthropogenic forests of the Northern Eurasia: high diversity of vascular plant and moss species; full set of microsites connected with a tree-fall mosaic; well-defined gap-mosaic; diversity of ecological-coenotic groups; uneven-aged structure of tree species populations; fertile soil and rich soil biota; presence of broad-leaved forest markers such as ephemeroids due to the presence of large-sized gaps within the forest; presence of broad-leaved tree species in paleo-spectra. Moreover, the northern dark coniferous forests may also be regarded as historic refugiua because they were less disturbed by humans and probably less exposed to fire.

The scientific research was performed by the Russian Foundation for Basic Research (project 19-0400-609) and partly supported by state assignment "Methodical approaches to the assessment of the structural organization and functioning of forest ecosystems" No. AAAA-A18-118052400130-7.

\section{References}

1. O. V. Smirnova, M. V. Bobrovsky, L. G. Khanina, European Russian Forest. Their Current State and Features of Their History (Springer, 2017)

2. D. L. Lugovaya, O. V. Smirnova, M. V. Zaprudina, A. A. Aleynikov, V. E. Smirnov, Russian J. of Ecol. 44, 3-10 (2013)

3. N. E. Shevchenko, O. V. Smirnova, Russian J. of Ecol. 48, 212-218 (2017)

4. A. A. Semikolennykh, A. D. Bovkunov, A. A. Aleinikov, Eurasian Soil Sci. 46(8), 821-832 (2013)

5. A. A. Goncharov, E. Y. Khramova, A. V. Tiunov, Eurasian Soil Sci. 47, 441-448 (2014)

6. A. P. Geraskina, Biol. Bull. 43(8), 819-830 (2016)

7. L. B. Zaugolnova, O. V. Smirnova, T. Yu. Braslavskaia, S. V. Degteva, T. S. Prokasina, D. L. Lugovaja, Veget. of Russia 15, 3-26 (2009).

8. A. A. Aleinikov, N. S. Smirnov, O. V. Smirnova, Russian J. of Ecol. 1, 3 (2016).

9. A. A. Aleynikov, O. V. Lisitsyna, N. A. Vladimirova, A. M. Krylov, L.V. Simakin, Lesotekhnicheskij zhurnal 3, 49-58 (2017)

10. O. V. Smirnova, D. V. Lugovaya, T. S. Prokazina, Biol. Bull. 3, 493-504 (2013)

11. O. Bachura, P. Kosintsev, Quarter. Intern. 160, 121-128 (2007)

12. D. Zhu, P. Ciais, J. Chang, G. Krinner, S. Peng, N. Viovy, J. Penuelas, S. Zimov, Nat. Ecol. Evol. 2, 640-647 (2018) 